\title{
The Important of Improving a Nutritional Status for Children with Disabilities
}

\author{
Nurul Hidayah', Baiq Fitria Rahmiati ${ }^{2}$, Junendri Ardian ${ }^{3}$, M. Thonthowi Jauhari' ${ }^{4}$, Qurratu \\ Aini $^{5}$, M. Zulfikar Al-fariqi ${ }^{6}$, Regina Pricilia Yunika ${ }^{7}$, M. Kevin Saputra ${ }^{8}$ \\ nurulhidayah@universitasbumigora.ac.id ${ }^{1}$, baiqfitria@universitasbumigora.ac.id ${ }^{2}$, \\ ardianjunendri@universitasbumigora.ac.id ${ }^{3}$, \\ thonthowi jauhari@universitasbumigora.ac.id ${ }^{4}$, qurratuainisabil17@gmail.com $^{5}$, \\ $\underline{\text { m.zulfikar@universitasbumigora.ac.id }^{6} \text {, reginapricilia@universitasbumigora.ac.id }}{ }^{7}$, \\ kevinsaputra24434@gmail.com ${ }^{8}$
}

1,2,3,4,5,6,7,8Universitas Bumigora

\author{
Article History: \\ Received: \\ Revised: \\ Accepted: \\ Keywords: Disability, stunting, \\ nutrition, voluntary program
}

\begin{abstract}
:
Disability is a special condition faced by some people. West Nusa Tenggara is at the top ten highest percentages for this special issue. This voluntary program was carried out to educate people how to maintain the diets of children in a special condition. The sharing programme was done by conducted a presentation, discussion, checking a height and weight and consultation. It was obtained that almost all parents having a kids with disability did not understand and were not aware how to prepare and choose food for their children. Approximately all children with a special issue at LombokCare community did not meet the standard heightfor-age of World Health Organization (WHO), meaning that they were stunted. Therefore, a new insight and better care practices were gained by the parents in order to control and prepare the balanced diets of their special children.
\end{abstract}

\section{Introduction}

Disability is a part of the condition faced by some people. Several researches mentioned it might be due to poverty; however, there are, as well, other factors responsible for this such as poor nutrition. In the accordance of The International Classification of Functioning (ICF), there are three human functioning issues; impairments, activity limitations, and participation restrictions; and disability is connected to difficulties faced in one or all areas of functioning (WHO, 2011).

It was assumed that there were between $4 \%$ and $11 \%$ persons with disability survived to live with their limits in Indonesia or at least approximately 10 million people (Cameron and Suarez, 2007). Figure 1, in Census 2010 based on Cameron and Suarez calculation (2007), depicts in 2017, there were a lot of majority faced seeing issues while $50 \%$ less than that were fighting for each hearing, walking, remembering and self-care problems. 


\section{ADMA}

Gurnal Pengabdian dan Pemberdayaan Masyarakat
Vol.1, No.1, June 2020, pp. 11-18

Doi: $x x x x x x x$

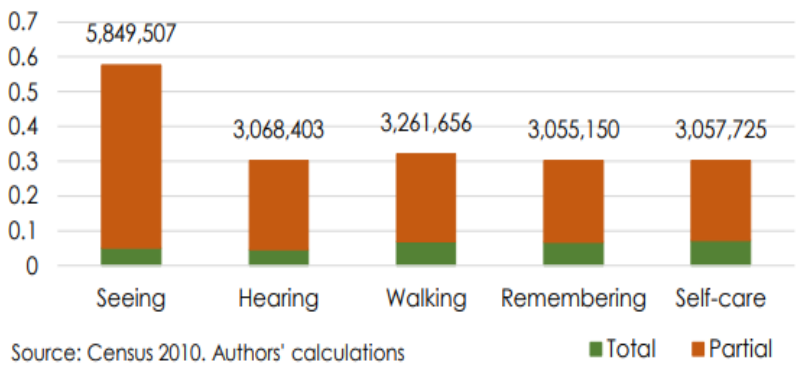

Figure 1. The data showing the percentage each impairment faced by persons in Indonesia

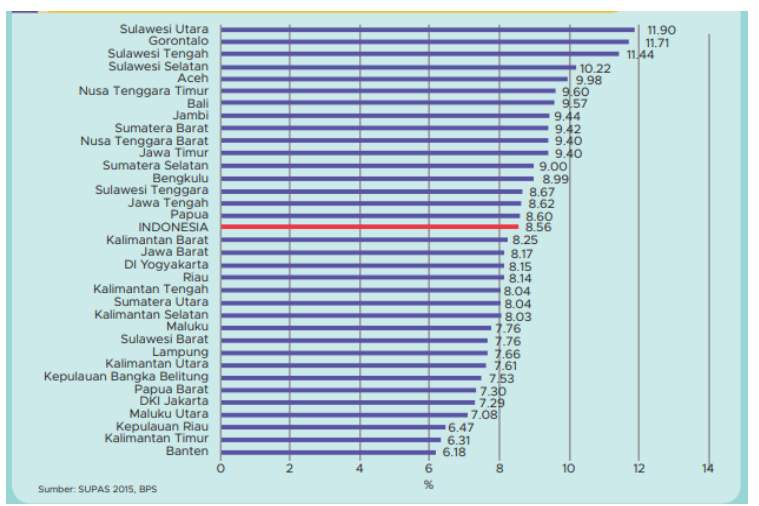

Figure 2. The percentage of disability in the area of Indonesia

Unluckily, West Nusa Tenggara (NTB) in SUPAS 2015 depicted on Figure 2 was reported on the top ten highest percentage $(9.40 \%)$ of disability (Ismandari, 2019). Even though the data depicted about $3 \%$ less than North Sulawesi and Gorontalo, the first and second highest prevalence of disability, it does not mean the issue should be neglected. The government, the experts, the researches, institution, society, even the parents must take responsibility for fighting together to combat the issue.

Luckily, West Nusa Tenggara (NTB) is not amongst the top ten highest rate of disability. Nevertheless, it does not mean NTB is already in a comfort zone, it needs an attention to reduce or at least to prevent. For the current case, this is not only government responsibility, but also institution, society and the environment.

Nowadays, there are a lot of Non-governmental organizations (NGO) and community services which facilitate with their needs, for instance school for disability and special teacher, physiotherapy, even a playground. One of the communities which have been working on this field is Yayasan LombokCare, an Indonesian foundation cooperated with Dutch community. Nevertheless, nothing seems perfect. This foundation is lack of information about how to manage the diet for the disability patients. In line with this, Nutrition bachelor programme at Universitas Bumigora tried to share the knowledge to educate not only the people engaged in Yayasan LombokCare but also the parents as a food controller for the kids with a special issue. The diet recommendation may not heal them directly; however, it might help increase the quality of their life, eating habit and behaviour improvements. 


\section{Method}

\section{a. Time and Place}

This activity was done at;

Time and date: 08:00, Thursday, 12 December 2019

Place: Aula LombokCare Foundation Jalan Biduri, Dusun Aik Are, Desa Sandik, Kec. Batulayar Kab. Lombok Barat, 83355Prov. NTB - Indonesia.

\section{b. Subject of activity}

All lecturers and students of Nutrition program at Universitas Bumigora went to the location together and this voluntary service was warmly welcomed by all members of Lombokcare community. Also, not only disable children (around 30 kids) who needed to attend but also all parents (approximately 50 people) were invited to join.

\section{c. Rundown Activity}

Table 1. The Rundown

\begin{tabular}{|l|l|l|l|}
\hline No & Activity & Time & Responsibility \\
\hline 1 & Opening & $08: 00-08: 30$ WITA & Lombokcare community \\
\hline 2 & $\begin{array}{l}\text { Sharing session by } \\
\text { presentation }\end{array}$ & $08: 30-09: 30$ WITA & $\begin{array}{l}\text { B. Fitria (Lecturer at } \\
\text { Universitas Bumigora) }\end{array}$ \\
\hline 3 & Discussion & $09: 30-11: 00$ WITA & $\begin{array}{l}\text { All Nutrition program's } \\
\text { lecturers of Universitas } \\
\text { Bumigora }\end{array}$ \\
\hline 4 & $\begin{array}{l}\text { Measuring height and } \\
\text { weight of disable children }\end{array}$ & $11: 00-12: 00$ WITA & $\begin{array}{l}\text { All Nutrition program's } \\
\text { students of Universitas } \\
\text { Bumigora }\end{array}$ \\
\hline 5 & Consultation session & $12: 00-13: 30$ WITA & $\begin{array}{l}\text { All Nutrition program's } \\
\text { lecturers of Universitas } \\
\text { Bumigora }\end{array}$ \\
\hline 6 & Closing and Photoshoot & $13: 30-14: 00$ WITA & $\begin{array}{l}\text { Lombokcare community } \\
\text { and Universitas Bumigora }\end{array}$ \\
\hline
\end{tabular}




\section{d. Strategies}

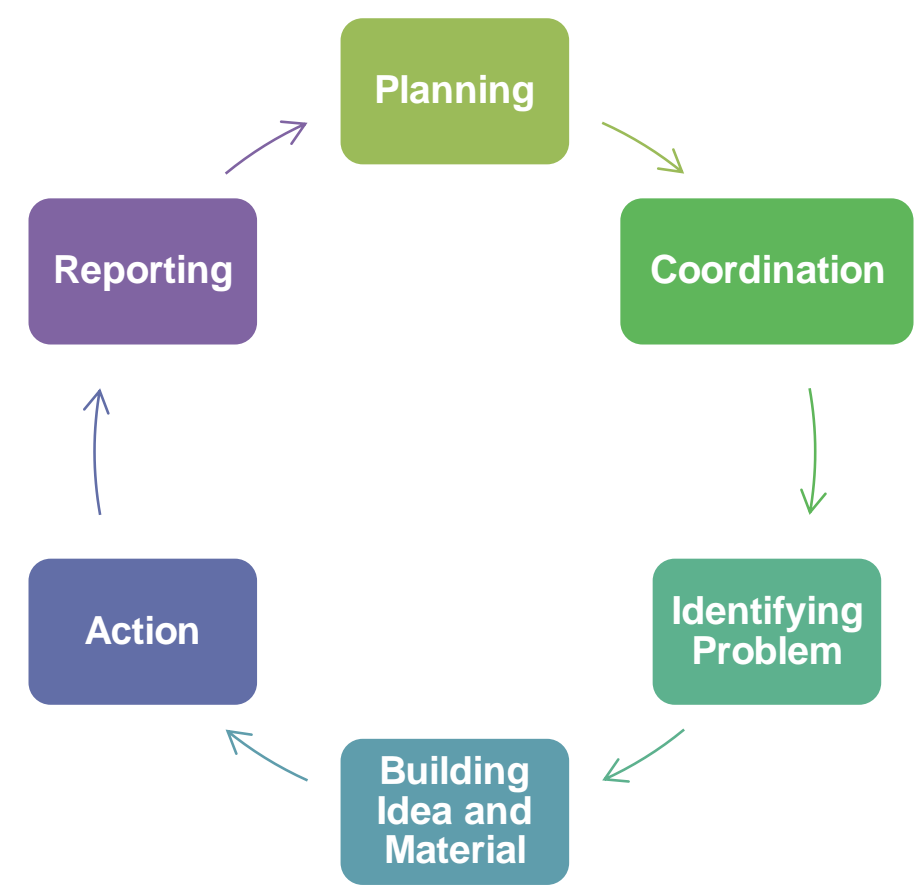

Figure 3. Method/strategy in conducting the programme

Before taking an action, we constructed a strategy based on;

1. Planning: The planning was based on the relationship between the study program and LombokCare community. Both parties decided to build up a relation. Lombokcare community, at that time, did not have enough knowledge and skills to cope their current situation, which in the ended had in contact with the study program to plan the voluntary service activity.

2. Coordination : Nutrition study program confirmed to LombokCare community that we would come and help solve the issue

3. Identifying Problem: Both parties shared the idea to deeply brainstorm the urgent problem

4. Building idea and material: All nutrition program lecturers discussed the concept and create a material which would be presented.

5. Action: All nutrition program's teachers and students came together to meet the parents, children and members' of LombokCare community to carry out the activity based on the rundown on table 1.

6. Report: All activities had to be put on the report containing a recommendation and advice which can be read by others.

\section{Results}

The voluntary service was carried out very well and smooth. All participants were enthusiast to join and all of them accompanied their special kids. There were three kinds of impairments found which were celiac, hyperactive and autism. The presentation given by the head of nutrition program, Baiq Fitria Rahmawati, M.Si brought about the parents to open up their mind about how important it is to control their children food. All parents admitted that they even did not understand how to choose the food for their kids. For that time, they just 


\section{ADMA}

Gurnal Pengabdian dan Pemberdayaan Masyarakat
Vol.1, No.1, June 2020, pp. 11-18

Doi: $x x x x x x x x$

followed their kid's intention without knowing it was appropriate or not in terms of health condition. The presentation told them what kind of food the parents should provide to the kids in that special circumstances. In fact, the kids still consumed unhealthy diets.

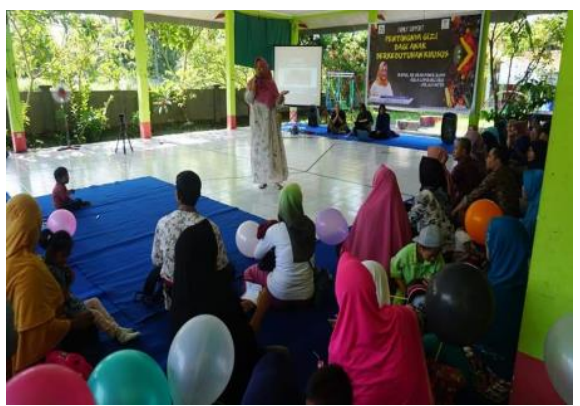

Figure 4. The sharing session by a presentation

At the discussion session, almost all parents complained that they could not meet the food suitable for the children. The questioned was about how to make their own diets and how to stay away the kids from snacking. They were a bunch of inquires which could not be answered one by one. They looked very curious about the answer and even the session was expired they were still waiting for the answer in the end of the agenda.

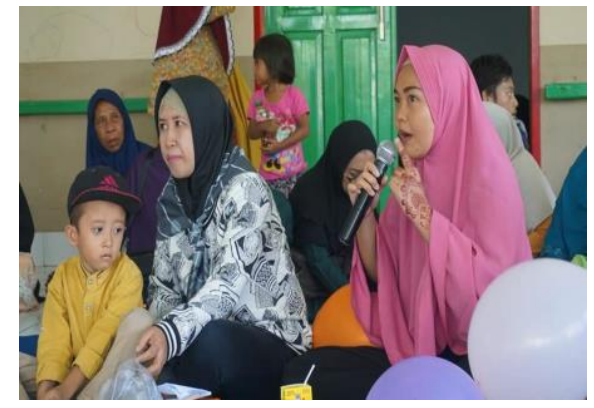

Figure 5. Discussion part

At the moment when the students would check the height and weight of the children, it was challenging to ask them because of their condition. Therefore, we needed a help from their parents or close relatives to guide them. After measuring the height and weight, it was found that most of the children not only facing the problem with the impairment like celiac, hyperactive and autism but also other health issue like stunting.

The parents, of course, consulted this condition. They asked the cause of stunting and how to deal with it. They did not gain a knowledge how to prepare the food in order to avoid other health issues.

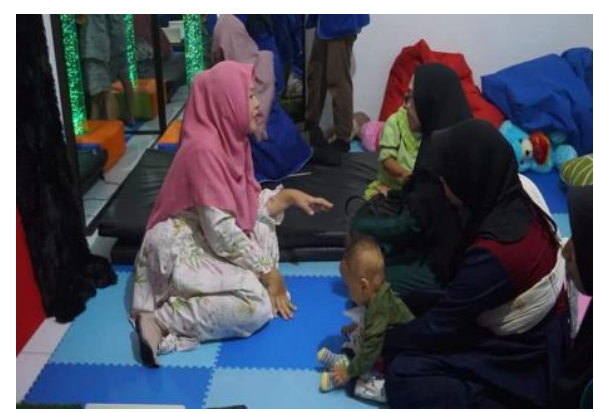

Figure 6. Consultation session 


\section{ADMA}

Gurnal Pengabdian dan Pemberdayaan Masyarakat
Vol.1, No.1, June 2020, pp. 11-18

Doi: $x x x x x x x x$

\section{Discussion}

According to the result, it was obtained that during the presentation the parents were very optimistic to join the activity since this was the first agenda which was held at LombokCare community focusing on nutritional status of the disable children. The parents gain much knowledge especially in terms of how to prepare and control diets for their own kids to meet the nutritional intake. This topic was opted for based on the issues faced in most of society. It is a kind of obstacle to always maintain what the disable children can eat properly. Groce et. all (2014) concluded that it is needed to fight together in this case; it can also be a chance to prevent or cope disability from doing nutritional services and programmes for children and adults.

The main point that was mentioned during the talk was about giving the food containing protein, carbohydrate, fat and other micronutrients. Ironically, the parents did not have an idea which food which was classified based on that nutrition. Luckily, during the discussion they gained the knowledge to identify the diets which have sufficient nutrition and suitable for their own children. UNICEF (2013) stated that a very young child and kids with disabilities probably need a special intake or more calorie supply to keep a healthy weight. Furthermore, the parents finally obtained an insight about free-gluten food which is recommended for the consumption. Gluten is a common name for one substance of protein used to form a dough structure which mostly is found in wheat, rye and barley. If it is consumed by celiac patients it might disturb an intestine (Hester, 2007).

Prior coming to this agenda, the participants admitted that they are not aware of what inside the food is, for example gluten and casein; however, now they start to apply the new notion to fulfil the recommended daily intake of their children. According to Nazni, Wesely, and Nashadevi (2008) preparing children with autism a diet without containing gluten and casein strictly resulted symptomatic improvements followed by a remarkable better condition. The consumption of Gluten-free and casein-free (GFCF) diet measured on children who are positively for celiac illness, allergy to milk and gluten brought about an advantage although it does not bear a dramatic impact on functioning or behaviour improvement in the case of children with autism spectrum disorder (ASD) (Hurwitz, 2013). In fact, it brings about the an advantageous impact on several gluten-related disorder, despite the fact that nutritional imbalances have been spoken (Khoury, Balfour-Ducharme, Joye, 2018).

Groce, at al., (2014) mentioned that, someone who was born with disability might have a high risk of nutritional issue. Many cases of malnutrition children were coming from disability (AbdAllah, El-Sherbeny and Khairy, 2007; Tüzün EH, Güven DK, Eker L, Elbasan B, Bülbül SF., 2013). Therefore, looking at the response or reaction of the participant during the discussion, this project is assumed to give a positive impact to improve eating habit and behaviour of disability children.

Moreover, nutrition deficiency was also analysed after the measurement of height and weight. Compared to the World Health Organization (WHO) Child Growth Standards median, the height-for-age for most of the children at LombokCare community did not meet the standard (the value under -2). This is obviously categorised stunting. Stunting occurs in the beginning of life due to lack of nutritional diets, improper feeding and care practices, but also a sickness such as gut problem (diarrhea) (UNICEF, 2013). Nevertheless, the parents in the end were given a consultation to cope the situation. They were advised to always check the food for their children consumption. The food must meet the nutritional daily intake to not 
only to improve the behaviour, cognitive and communication of children in a special condition but also to shape a better eating habit.

\section{Conclusion}

The program carried out to take care the balanced diet of disability children (celiac, autism and hyperactive) at Lombokcare community positively affected the participants, not only the children but also the parents even the members of community who together work on this. The parents can finally recognise suitable diets which have to be prepared for their kids by looking at the content or nutrition. They become more aware to their kids' daily intake and think smarter before buying the foods. While stunting is another problematic issue which has to be eliminated together. This is not only the responsibility of the parents but also us, as a nutritionist and food technologist.

\section{Acknowledgements}

Eventually, Thanks to Allah swt. We could finish this article. Not to mention, we thank to Universitas Bumigora, the students of nutrition study programme, LombokCare community, the parents and the special children worldwide surviving with their specialty. Let's go together to a better life. "If there is a will, there will be a way"

\section{Daftar Pustaka}

AbdAllah, A. M., El-Sherbeny, S.S.A. and Khairy, S. (2007). Nutritional Status of Mentally Disabled Children in Egypt, Nutritional Biochemistry Department, Nutrition Institute Nutritional Requirement and Growth Department, Nutrition I. The Egyptian Journal of Hospital Medicine, 29, 604-615.

Cameron, L., \& Suarez, D. C. (2017). Disability in Indonesia: What can we learn from the data?, https://www.monash.edu/ data/assets/pdf file/0003/1107138/Disability-in-Indonesia.pdf

El Khoury, D., Balfour-Ducharme, S., \& Joye, I. J. (2018). A review on the gluten-free diet: Technological and nutritional challenges. Nutrients, 10(10), 1-27. https://doi.org/10.3390/nu10101410

Groce, N., Challenger, E., Berman-Bieler, R., Farkas, A., Yilmaz, N., Schultink, W., Kerac, M. (2014). Malnutrition and disability: Unexplored opportunities for collaboration. Paediatrics and International Child Health, 34(4), 308-314. https://doi.org/10.1179/2046905514Y.0000000156

Hester, J. (2007). The management of chronic pain: pain management and other self help programmes. The British Pain Society Newsletter, Winter.

Hurwitz, S. (2013). The Gluten-Free, Casein-Free Diet and Autism: Limited Return on Family Investment. Journal of Early Intervention, 35(1), 3-19. https://doi.org/10.1177/1053815113484807

Ismandari, F. (2019). Situasi Disabilitas, 1-10. Kementerian Kesehatan RI Pusat Data dan Informasi.

Nazni, P., Wesely, E. G., \& Nishadevi, V. (2008). Impact of casein and gluten free dietary intervention on selected autistic children. Iranian Journal of Pediatrics, 18(3), 244-250.

Tüzün, E. H., Güven, D. K., Eker, L., Elbasan, B., \& Bülbül, S. F. (2013). Nutritional status of children with cerebral palsy in Turkey. Disability and Rehabilitation, 35(5), 413-417. https://doi.org/10.3109/09638288.2012.694965 


\section{ADMA}

Jurnal Pengabdian dan Pemberdayaan Masyarakat
Vol.1, No.1, June 2020, pp. 11-18

Doi: $x x x x x x x$

UNICEF, 2013. The State of The World Children 2013, Children with Disability. Flagship report. www.unicef.org/SOWC2013 Accessed 16 Mei 2020

WHO. (2011). Chapter 1: Understanding disability. WHO. World Report on Disability. Malta: WHO, 117. https://doi.org/http://dx.doi.org/10.2471/BLT.16.181636 